ENTREPRENEURSHIP AND SUSTAINABILITY ISSUES

ISSN 2345-0282 (online) http://jssidoi.org/jesi/

2020 Volume 8 Number 2 (December)

http://doi.org/10.9770/jesi.2020.8.2(67)
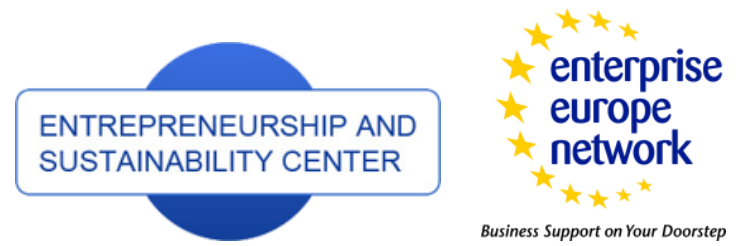

Business Support on Your Doorstep
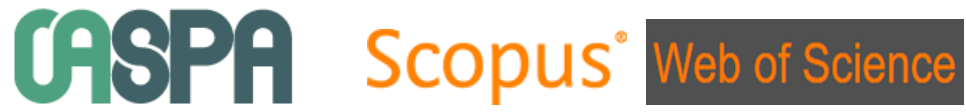

http://issidoi.org/esc/home

Publisher
oi.org/esc/home

\begin{abstract}
Clarivate
Analytics
\section{RESEARCH ON THE EFFECT FACTORS OF TECHNICAL PERFORMANCE ON SMEs BY INDUSTRIAL SECTORS*}

\author{
Graduate School of Knowledge Service Consulting, Hansung University, P. O. Box 136-792, 16th Street, \\ Samseonggyo-ro, Seongbuk-gu, Seoul, Korea
}

Seok-Soo Kim
\end{abstract}

E-mail:ssjm4475@gmail.com

Received 7 July 2020; accepted 13 October 2020; published 30 December 2020

\begin{abstract}
This study's research question is that there will be a crucial element in improving business performance among SMEs' success variables and competencies. Significantly, there should be different variables for performance in industry sectors. 1) The success variables of SMEs vary widely, but four characteristics of technology, management, commercialization, and exit strategies were selected. 2) The mediator is a technology innovation and technology marketing function. 3) The dependent variables are technical, financial, and nonfinancial performance. Previous literature had problems studying only the effects of each of the three variables, so we established a hypothesis and research model that focused on causality studies linking them. According to the data group analysis result for 3330 CEOs of SMEs, the six industries' performance impact factors were different. As a result of comparative analysis of changes in performance impact by industry, it was found that the largest increase in Information Technology (IT)/Software (S/W), Life/Food, and Crafts sectors. The key research finding is that it has verified the essential elements of critical performance improvement. We provided that different success variables and competencies differ in performance across industries. The results are expected to contribute to SMEs' CEO and government policymakers' practical applications, support organizations, academia, and industry.
\end{abstract}

Keywords: entrepreneurial performance; entrepreneurial competency; SMEs; technical performance; effet factor; technology commercialization

Reference to this paper should be made as follows: Seok-Soo, Kim. 2020. Research on the effect factors of technical performance on SMEs by industrial sectors. Entrepreneurship and Sustainability Issues, 8(2), 1120-1141. http://doi.org/10.9770/jesi.2020.8.2(67)

JEL Classifications: O32, L26, M13, D22, L21, L53

\footnotetext{
* This research was financially supported by Hansung University, Korea
} 


\section{ENTREPRENEURSHIP AND SUSTAINABILITY ISSUES}

ISSN 2345-0282 (online) http://jssidoi.org/jesi/

2020 Volume 8 Number 2 (December)

http://doi.org/10.9770/jesi.2020.8.2(67)

Make your research more visible, join the Twitter account of ENTREPRENEURSHIP AND SUSTAINABILITY ISSUES: @Entrepr69728810

\section{Introduction}

This study examined the concepts of entrepreneurs' success variables and entrepreneurs' competencies that can enhance technology-based SMEs' business success to revitalize the technology-based entrepreneurship ecosystem. Besides, by analyzing the impact and analyzing the impacts' characteristics, we verified the impacts of the success factors on the entrepreneurial competency and identified the correlations. To achieve this goal, we reviewed the problems and limitations of previous studies through literature review and then explored the factors to derive, analyze, and evaluate the core factors. Theoretical research systematically analyzed previous studies related to the Technical Performance and influential factors of technology start-up companies that have been studied in Korea and abroad. In particular, this study examined the effects of technology start-up companies' success variables on the technology marketing capability and technology innovation capacity, which are the mediating effects of technology startup capability. Also, we verified the impact of the technology startup success variables on the business performance of technology startup companies, set up a research model, and performed research on the effects through Smart PLS.

The survey subjects were 330 start-up companies' CEO and conducted online surveys in six industries, types of manufacturing, and gender, and 205 questionnaires were collected and used for empirical analysis. For statistical analysis, SPSS 22 was used for basic statistical analysis. The results were presented using Smart PLS3.2.9 for evaluation and significance evaluation of the research model's measurement and structural models. We Investigated the components of entrepreneurs' ability to perform entrepreneurship under poor entrepreneurship conditions and evaluated their influence to improve their ability and capacity for success of start-ups based on the characteristics of the entrepreneurs' capabilities and the conditions of their establishment. Creating and expanding business performances by linking core competencies and starting a business to successful start-ups is an important task.

We reviewed previous studies to identify problems and limitations and select variables. Success variables have been studied in various ways. However, in this study, technology, management, commercialization, and exit strategies have been selected because they are essential success variables for companies. The mediation variables are SMEs' technology marketing competency and technology innovation competency, which affect performance and verify the mediating effect on performance. The dependent variables are financial performance, non-financial performance, and Technical Performance, which are indicators of performance. The objectives of this study are as follows. First, the causal relationship between the success variables of SMEs on competence and performance. Second, the effect of success variables on performance through the mediating effect of competency. Third, the effect of competency on performance. Fourth, the effect on the performance of six industries including electrics/electronics, machinery/parts, IT/SW, chemicals/textiles/materials, life/food, crafts/others. The reason for selecting six industrial classifications is that, since 2001, the Korea Startup Promotion Agency has been operating a business support policy by designating six industrial classifications of small and medium-sized startups.

\section{Theoretical background}

Previous research on technology-based SMEs: Technology-based startups and ventures already play a significant role in developing the national economy and serve as a growth engine for industrial innovation (Autio 1997; Kortum and Lerner 2001). A company focused on R and D or using new technical knowledge or knowledge (Cooper, Williard and Woo 1986). In Korea, it is classified into technology-based startups, ventures, and general startups according to the type of startup of the Small and Medium Business Administration and the Korea Startup Association. Small and medium-sized startup companies are identified as new technology-based companies that 


\section{ENTREPRENEURSHIP AND SUSTAINABILITY ISSUES}

ISSN 2345-0282 (online) http://jssidoi.org/jesi/

2020 Volume 8 Number 2 (December)

http://doi.org/10.9770/jesi.2020.8.2(67)

Make your research more visible, join the Twitter account of ENTREPRENEURSHIP AND SUSTAINABILITY ISSUES: @Entrepr69728810

have just been established. Within seven years, which mainly corresponds to the manufacturing and knowledge service industry, the Small and Medium Business Startup Support Act defines a company within seven years after its establishment as a startup company. In a similar sense, it means a new SME that is technology-intensive as a venture company. It is also recognized as a result of high-tech or new technology-based startups with high risk and high-profit potential. However, the definition is similar because the distinction is not clear. Examples include spin-offs, technology-based spin-offs, new technology-based companies, research-based ventures, and high-tech startups (De Cleyn and Braet 2009). In another respect, research-based startups are defined as new business startups that develop and sell new products or services based on proprietary technologies, and research, development, innovation, exports, and employment. In this regard, small and medium-sized startups have contributed to the economy and have played a key role in bringing new technologies to the market (Heirman and Clarysse 2004). A small and medium-sized start-up company means a start-up based on the entrepreneur's skills, experience, and expertise, and is also called a start-up technology. The United States recognizes that technologybased start-ups are accompanied by personal and collective assets associated with advances in scientific and technical knowledge to create and maintain value (Bailetti 2012).

In Korea, as of April 2019, according to the 2018 Entrepreneurship Research Results Report, there were 2,030,987 small and medium-sized startups. The organization type was $89.0 \%$ for individual entrepreneurs and $11.0 \%$ for corporate entrepreneurs. The distribution of organizational form by industry was high for individual entrepreneurs from 1 st to 7 th year. Corporate entrepreneurs were found to maintain similar levels at around $10 \%$. The start-ups in one year accounted for the largest portion with $24.3 \%$, followed by $20.6 \%$ in 2 years, $16.0 \%$ in 3 years, $12.6 \%$ in 4 years, $10.2 \%$ in 5 years, $8.8 \%$ in 6 years, and $7.5 \%$ in 7 years. In terms of 18 major categories, $26.5 \%$ of the wholesale and retail industries were the highest, followed by $25.8 \%$ of the lodging and restaurant industry, $8.9 \%$ of the manufacturing industry, and $7.8 \%$ of repair and other personal service industries (Start-up Promotion Agency 2019).

The results of researching previous studies on the performance of SMEs can be summarized as follows. The effect of management ability on financial performance was studied (Kim and Seo 2017). The effects on technology competency, Technical Performance, and management performance were also studied (Lee I.K 2016). However, the previous studies were limited to each of the influence variables. Also, only the success variable's management performance was studied in part, and there was no study on the mediating effect of SMEs' competency. Overall, the previous study was only to identify success variables for management performance and individual relationships of competencies. Therefore, some problems and limitations cannot determine the causal or dynamic relationship between variables.

The specific purpose of this study is as follows. First, the causal relationship examined empirically, the effects of the technology startup success variables on capability, and the Technical Performance of technology startup companies. Second, this study empirically analyzed the effect of the technology startup success variables on technology performance through the mediating effect of technology startup capability. Third, we empirically identified the effect of technology entrepreneurship capability on technology start-up companies' Technical Performance. Fourth, empirically analyzed the influence factors of technology startup success variables on technology performance by using Partial Least Square-Structural Equation Modeling (PLS-SEM), a statistical analysis technique, and causal relationship. Fifth, identified the impact factors affect business performance in six industries such as electrics/electronics, machinery/parts, IT /SW, chemicals/textiles/materials, life/food, crafts, and other industries. The moderating effect of differences performance was confirmed using Data Group Analysis. 


\section{ENTREPRENEURSHIP AND SUSTAINABILITY ISSUES}

ISSN 2345-0282 (online) http://jssidoi.org/jesi/

2020 Volume 8 Number 2 (December)

http://doi.org/10.9770/jesi.2020.8.2(67)

Make your research more visible, join the Twitter account of ENTREPRENEURSHIP AND SUSTAINABILITY ISSUES: @Entrepr69728810

This study's differences are summarized as follows: 1) The success variable, an independent variable, was selected as four sub-factors. Management performance, a dependent variable, was selected as three sub-factors: technical performance, financial performance, and non-financial performance. 2) As a parameter, a sub-factor of competency, the effect on business performance was studied by selecting technology innovation competency and technology marketing competency. 3) The relationship between the entrepreneur's business and the impact on management performance according to industry was compared and verified.

\section{Theory and hypotheses}

As we looked at the effect of success variables on the SMEs' competency and management performance in the theoretical background: it has been found that previous studies have failed to comprehensively study potential influence variables such as management ability, technical ability, exit strategy, technology commercialization competency, and technical marketing competency. Therefore, in this study, the success variables were studied not only on the effect on corporate competency and business performance but also on SMEs' competency in management performance.

We established three hypotheses to test these research topics. Technical expertise and management skill were studied as factors influencing SMEs' innovation capability and competitiveness (Hwang, Choi and Shin 2020). The research model suggested that technological competence will have a positive (+) effect on the core competency of small and medium-sized entrepreneurs. (Kim, Cho and Lee 2020). According to entrepreneurs, six startup success factors were studied (Prohorovs, Bpositively 2019). Therefore, the success variables expected to affect the entrepreneurs' ability to be studied sporadically in previous studies were summarized as external factors such as entrepreneurship education, government support, and investment were excluded. In this study, it was necessary to study the entrepreneurs' success and technical factors as factors that influenced entrepreneurs' success, excluding external factors. Therefore, there is a need to verify the effect of SMEs' competency on technology and management. For this reason, entrepreneurs propose the following hypothesis.

\section{Hypothesis 1. Entrepreneurial success variables will have a positive effect on competency.}

As an independent variable, the effect of corporate competencies on the success of business incubators was studied (Pauceanu, Alpenidze, Edu and Zaharia 2019). The dynamic competencies positively impact the business performance of start-ups was presented (Seo and Lee 2019). An empirical study on the effect of technology commercialization competency on management performance, technical competency, and marketing competency as a control variable for technology commercialization competency as independent variables was studied (Park and Yang 2018). An empirical research model on the impact of performance and technology commercialization competency was presented (Bae, Song and Kim 2018). Technology innovation and commercialization competencies studied the effect of management performance (Kim and Park 2018). Therefore, the necessary competencies that affect performance as the number of mediating success variables need to focus on technological competencies and verify their effectiveness. The reason was that it was necessary to test the hypothesis that in order to create business results, there would be necessary variables that mediate success factors. External factors such as entrepreneurship, government support, and investment were excluded. As a mediator of entrepreneurs' success, excluding external influences, it was necessary to focus and study the technical factors. Therefore, there is a need to verify the performance impact on the technical side. For this reason, the following hypothesis was proposed.

\section{Hypothesis 2. SMEs' competencies will have a positive impact on performance.}


ENTREPRENEURSHIP AND SUSTAINABILITY ISSUES

ISSN 2345-0282 (online) http://jssidoi.org/jesi/

2020 Volume 8 Number 2 (December)

http://doi.org/10.9770/jesi.2020.8.2(67)

Make your research more visible, join the Twitter account of ENTREPRENEURSHIP AND SUSTAINABILITY ISSUES: @Entrepr69728810

The effect of SMEs' CEO technology competency on management performance was studied (Lee I.K. 2016). A research model was presented on the impact of technological competency on management performance (Yoon, J.H. 2018). Knowledge and networks in the global start-up process study suggested a network (Englis, Wakkee and Van Der Sijde 2007). The effect of core competencies and network competencies on SMEs' management performance was studied (Kim and Bang 2017). An effect of network competency on technological innovation capability and innovation performance was studied (Kim, J.Y. 2017). Therefore, it was found that the success variables affecting business performance were studied from various perspectives. In this study, it was divided into a management perspective and a technical perspective. In terms of management, it is necessary to categorize it into four sub-factors: management and exit strategies, technical ability, and technical commercialization ability, to verify the effectiveness. The reason is that to create business results, and it is difficult to identify the effect factors without excluding external factors. As a variable of success for entrepreneurs, it was necessary to study focusing on technology and management factors, excluding external influences. Therefore, the following hypothesis was proposed.

Hypothesis 3. Success variables will have a positive effect on Technical Performance.

The conceptual research model is shown in Figure 1.

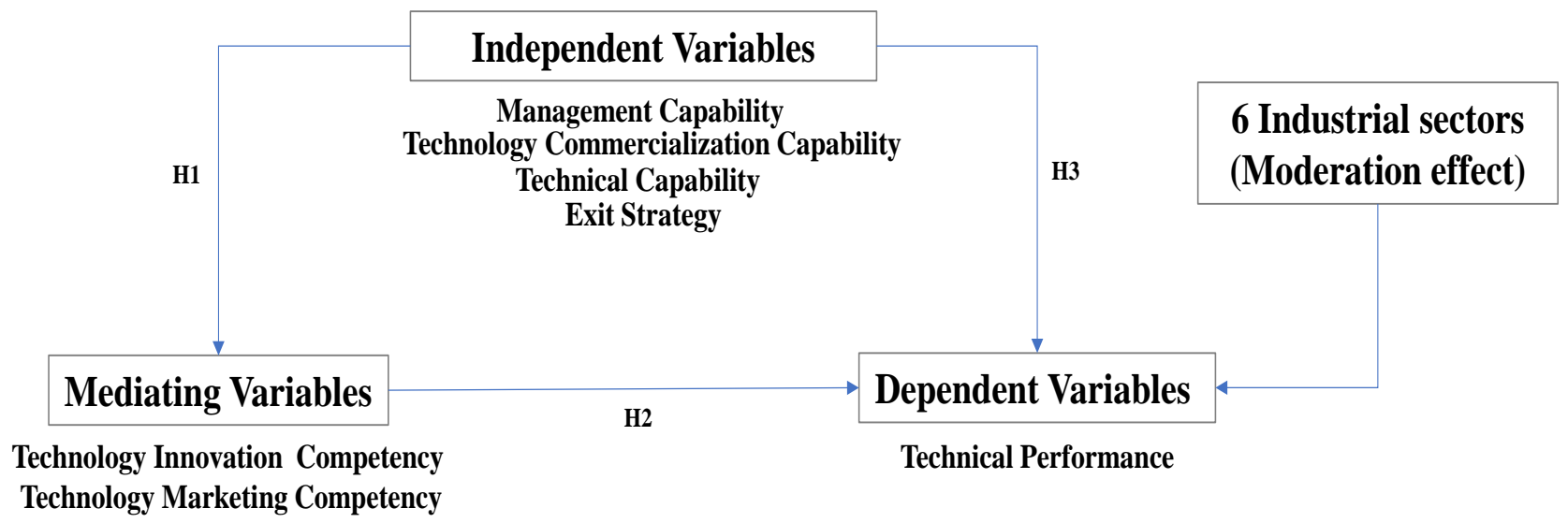

Figure 1. Conceptual research model

Studies on differences in performance and impact according to SMEs' industrial classification were not found in previous studies. It is very commercially meaningful in that it can provide a realistic and feasible alternative. This study confirmed whether there is a difference in the size of the impact on the industry sector's business performance. Using Data Group Analysis (DGA) to validate the differences in competency and business performance across six industries is a unique and differentiated point from previous studies. The final structural study model is shown in Figure 2. 
ENTREPRENEURSHIP AND SUSTAINABILITY ISSUES

ISSN 2345-0282 (online) http://jssidoi.org/jesi/

2020 Volume 8 Number 2 (December)

http://doi.org/10.9770/jesi.2020.8.2(67)

Make your research more visible, join the Twitter account of ENTREPRENEURSHIP AND SUSTAINABILITY ISSUES: @Entrepr69728810

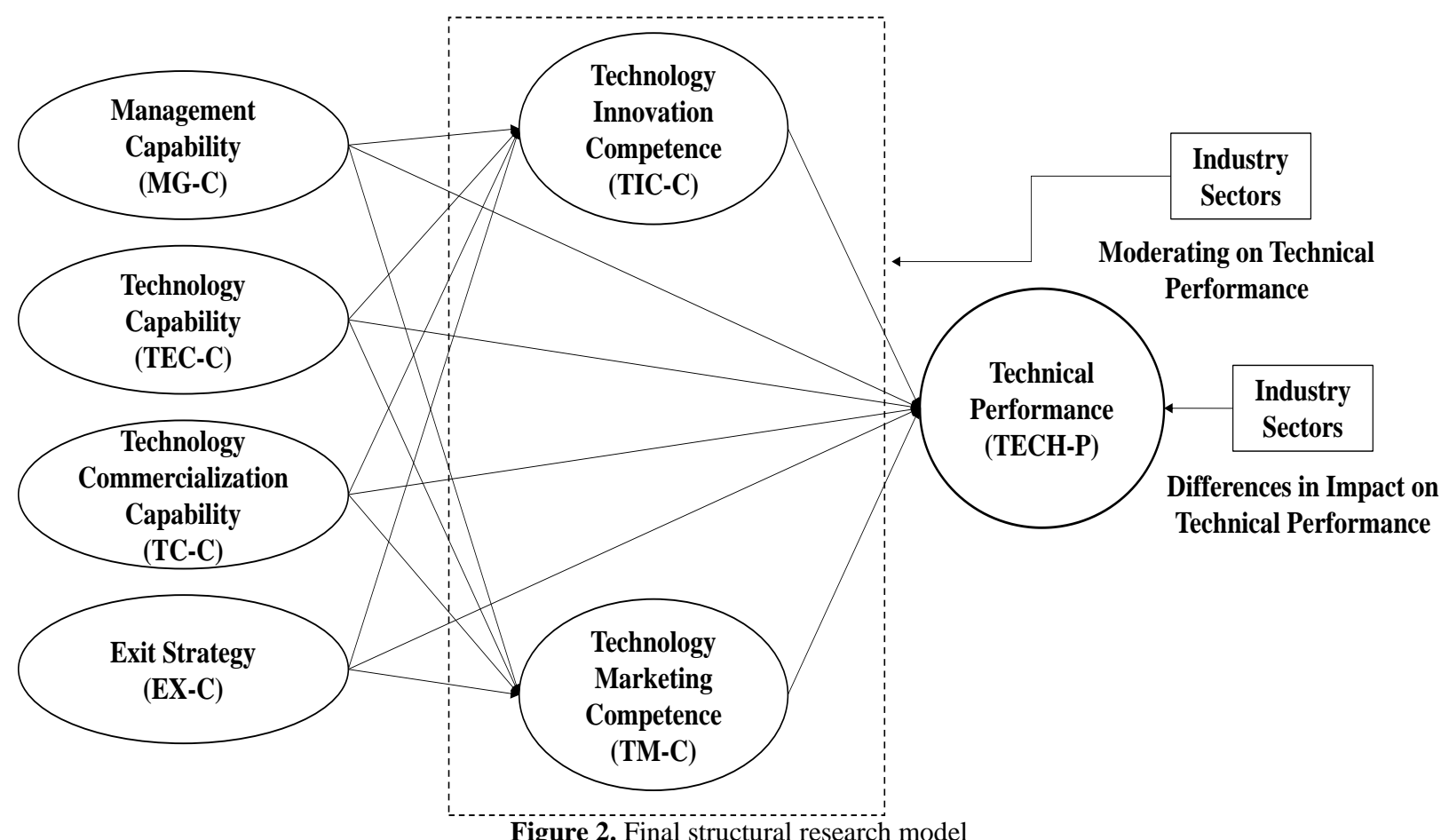

\section{Materials and methods}

The data was collected using an online questionnaire method for 330 CEOs of SMEs based on manufacturing. The questionnaire was collected from 205 CEOs, and the response rate was 62\%. SMEs are less than five years after the start-up. The industrial sector is six fields defined in Korean start-up company classification criteria: electrics/electronics, machinery/parts, IT/SW, chemicals/textiles/materials, life/food, crafts/others. The 5-point scale was used to measure the questionnaire. The collected data were analyzed and verified along with the basic statistics and measurement and structural models by SPSS 22 and Smart PLS 3.2.9. Among the collected data, insignificant measurement indicators were removed through factor analysis. To confirm the reliability and validity required for evaluating the reflex measurement model, the internal consistency reliability, convergence validity, and discriminative validity were evaluated by running the PLS algorithm. The internal consistency reliability was evaluated by Cronbach's $\alpha$, Dijkstra-Henseler's rho_A, and Composite Reliability (CR). Outer loadings, measurement variable reliability, evaluated the convergent validity, Average Variance Extracted (AVE). Discriminant validity in a reflective measurement model was assessed using Fornell-Larcker Criterion (FLC), cross-loading (Hair et al. 2017).

The model of this study consisted of a reflective measurement model consisting only of reflective indicators. The collected data were analyzed first using SPSS, and the analysis of factors was used to remove insignificant measurement indicators. In this study, internal consistency reliability, concentration validity, and discriminant validity were analyzed and evaluated. Cronbach's $\alpha$, Dijkstra-Henseler's rho_A, and Composite Reliability (CR) of internal consistency reliability assessment are criteria for evaluating internal consistency reliability, and Average Variance Extracted (AVE) is a criterion for evaluating concentration validity. If the AVE square root of the diagonal is larger than the correlation between the study variables below the diagonal, the discriminant validity 


\section{ENTREPRENEURSHIP AND SUSTAINABILITY ISSUES}

ISSN 2345-0282 (online) http://jssidoi.org/jesi/

2020 Volume 8 Number 2 (December)

http://doi.org/10.9770/jesi.2020.8.2(67)

Make your research more visible, join the Twitter account of ENTREPRENEURSHIP AND SUSTAINABILITY ISSUES: @Entrepr69728810

between the study variables is evaluated. For the evaluation results and interpretation of the reflective measurement model, Fornell-Larcker Criterion was used for external loading, measurement variable reliability, AVE value, Cronbach's $\alpha$, rho_A, Composite Reliability (CR), and discriminant validity. PLS-SEM performs Bootstrapping and Blindfolding to evaluate the reflected structural model and verify the hypothesis, and then verify and analyze the multicollinearity, coefficient of determination $\left(\mathrm{R}^{2}\right)$, effect size $\left(\mathrm{f}^{2}\right)$, and predictive suitability $\left(\mathrm{Q}^{2}\right)$. Finally, we confirmed that the structural model was suitable and evaluated the path coefficient's significance and the model's suitability. Lastly, by introducing industry-specific variables, we confirmed the difference in influence by industry. By verifying the influence on the moderating effect on business performance as a dependent variable, we confirmed that this study's model was suitable and found that it had a moderating effect.

The demographic characteristics are as follows. The gender distribution was $66.8 \%$ for men and $33.2 \%$ for females, respectively, and the proportion of males was $60.5 \%$ for a private company and $39.5 \%$ for corporate companies. In the industry sectors, electrics/electronics $18.5 \%$, machinery/parts $14.8 \%$, IT/SW $17.6 \%$, chemicals/textiles/materials $17.6 \%$, life/food $12.7 \%$, and crafts/others $19.0 \%$. Regarding the number of years of respondents' start-ups, 32.2\% was less than two years or less than three years, $32.2 \%$ was less than one year, or less than two years, less than $7.3 \%$, more than five years $4.9 \%$. Looking at the sales volume of t,he previous year, less than 0.1 million $\$$ was the highest with $35.1 \%$, followed by $32.2 \%$ from 0.1 million $\$$ to less than 0.3 million \$, $22.0 \%$ from 0.3 million $\$$ to less than 0.5 million $\$$, and less than 0.5 million $\$$ to 1 million $\$ 9.3 \%, 1$ million $\$$ or more $1.3 \%$. In terms of the manufacturing method, outsourcing and in-house manufacturing accounted for the largest share at $62.0 \%$, outsourcing $22.9 \%$, and $15.1 \%$. In terms of the number of employees, less than three people were the most $46.3 \%$, more than three and less than six people were $39.0 \%$, more than five and less than ten people were $13.7 \%$, more than ten people were $1.0 \%$. By age group, the 30 s were the highest with $40.0 \%$, the 40 s were $38.5 \%$, the over 50 s were $12.7 \%$, and the 20 s were $8.8 \%$.

\section{Independent variables}

\section{Management ability}

As a study on the manager's psychological characteristics, it means that creative innovation that enables the development of new products, technologies, and procedures through new ideas, development, and research and development through innovation of management characteristics (Franco, Hope and Lu 2017). Research on management ability is significant because it can explain the relationship between the manager's differences and management performance more systematically and concretely than research based on its characteristics. The evaluation of observable management ability can give the company's manager a direction for the company's development. Early-stage SMEs are not precisely organized, so there is a limit to creating results based on the organization's capabilities. Although management abilities vary from time to time in each study, technical competence, strategic thinking ability, and organizational competency are considered to be very important in common (Andreou, Karasamani, Louca and Ehrlich 2017).

\section{Technical ability}

Technical ability is an essential resource for promoting and supporting a company's innovation strategy and sustainable success and as an important result of innovation activities (Burgelman and Sayles 2004). The company's technical ability was presented in seven categories: learning ability, R and D ability, resource allocation ability, production ability, organizational ability, and strategic planning ability (Yam et al. 2004). 
ENTREPRENEURSHIP AND SUSTAINABILITY ISSUES

ISSN 2345-0282 (online) http://jssidoi.org/jesi/

2020 Volume 8 Number 2 (December)

http://doi.org/10.9770/jesi.2020.8.2(67)

Make your research more visible, join the Twitter account of ENTREPRENEURSHIP AND SUSTAINABILITY ISSUES: @Entrepr69728810

Technology commercialization ability

In a narrow sense, technology commercialization is limited to how products or services are created after the basic research or development stage, which is a technology development activity. New technologies acquired through own research and development or external procurement can be defined as a continuous process from prototype manufacturing, pilot production, mass production system construction, marketing, and sales activities to link actual production and sales (Nevens 1990). It has been reported that systematic technological innovation ability and technology commercialization ability affect management performance by revealing that a long-term strategic plan is being made (Booz, Allen and Hamilton 1982).

Exit strategy ability

A study was conducted on the exit strategies of SME managers (Kim, S.Y 2014). The venture company's EXIT strategy and cases by type were studied (Kwon, O.H 2009). An empirical study was conducted on business commercialization and technological innovation on management performance (Bae, H.B., Song, M.K., and Kim, S.G 2018).

\section{Mediating variables}

\section{Technology innovation competency}

Technology innovation competency is critical that leads to the continuous growth of a company. At the same time, it is a characteristic of a comprehensive company that promotes and supports technological innovation (Burgelman, Christensen and Wheelwright 2008). On the other hand, it was analyzed that the relationship between $\mathrm{R}$ and $\mathrm{D}$ investment level and business performance was negative or not at all (Coombs and Bierly 2006). In a study of the technological innovation system framework and the entrepreneur's view of innovation, the technological innovation system-generated valuable insights into the processes that need stimulation for the successful development and implementation of innovative sustainability technologies (Planko, Cramer, Hekkert, and Chappin 2017). It has been shown whether innovation capacity positively affects the company's performance (Saunila 2017).

\section{Technology marketing competency}

Viewing the results of the analysis of the success or failure of technology development, marketing's importance is reduced. In other words, $20 \sim 40 \%$ of the technical failures are due to defects in the technology itself (Miller and Power 2005). A rest is due to the lack of marketing competency, especially in high-tech products, due to the lack of marketing competency reaching 75\% (Clugston 1995). The concept of technology marketing is interpreted differently depending on the researcher and expressed in two ways. As a unique research area of marketing, it is a high-tech product marketing that sells or purchases products with technology-typed products through marketing techniques.

\section{Dependent variables}

\section{Technical Performance}

Technical Performance has a relatively large effect on technical and technical management competency, production support, marketing competency, research and development competency, and new product development competency. It has a significant impact on market information as well as business performance. It is said that the securing of superior technology can directly act as a determinant of investment by venture capital or other 
ENTREPRENEURSHIP AND SUSTAINABILITY ISSUES

ISSN 2345-0282 (online) http://jssidoi.org/jesi/

2020 Volume 8 Number 2 (December)

http://doi.org/10.9770/jesi.2020.8.2(67)

Make your research more visible, join the Twitter account of ENTREPRENEURSHIP AND SUSTAINABILITY ISSUES: @Entrepr69728810

investment companies because it is directly related to the growth or profits of venture companies (Johannisson 1986).

\section{Results}

\section{Evaluation of the measurement model}

The evaluation of the research model's measurement model was carried out using the PLS Algorithm of Smart PLS 3.2.9 to analyze and evaluate internal consistency reliability, concentration validity, and discriminant validity. PLS path modeling was developed by Wold (1982), which is essentially a regression sequence in the form of a weight vector. The weight vector obtained at convergence satisfies the fixed-point formula (Dijkstra 2010). The PLS Algorithm execution basic setting for evaluating the reflective measurement model was performed using the path weighting method, the maximum repetition 1000 times, and the stopping criterion set to $10^{-7}$. Internal consistency reliability was assessed by Cronbach's Alpha, Dijkstra-Henseler's rho_A, and Composite Reliability (CR). The convergent validity by outer-loadings, measurement variable reliability, and AVE. The results are shown in Table 1.

Table 1. Evaluation results of the reflective measurement model

\begin{tabular}{|c|c|c|c|c|c|c|c|c|}
\hline \multirow{3}{*}{$\begin{array}{l}\text { Type of } \\
\text { variables }\end{array}$} & \multirow{3}{*}{$\begin{array}{c}\text { Latent } \\
\text { variable* }\end{array}$} & \multicolumn{3}{|c|}{ Convergent validity } & \multicolumn{3}{|c|}{ Internal consistency reliability } & \multirow{3}{*}{$\begin{array}{l}\text { Discriminant validity } \\
\text { Cross loadings }\end{array}$} \\
\hline & & $\begin{array}{l}\text { Outer } \\
\text { loadings }\end{array}$ & $\begin{array}{c}\text { Measuremen } \\
\text { variables } \\
\text { reliability }\end{array}$ & AVE & Cronbach's Alpha & $\begin{array}{c}\text { Dijkstra- } \\
\text { Henseler's } \\
\text { rho_A }\end{array}$ & $\begin{array}{c}\text { Composite } \\
\text { reliability } \\
\text { (CR) }\end{array}$ & \\
\hline & & $>0.7$ & $>0.5$ & $>0.5$ & $0.5 \sim 0.9$ & $>0.7$ & $0.5 \sim 0.9$ & \\
\hline \multirow{4}{*}{$\begin{array}{c}\text { Independent } \\
\text { variable }\end{array}$} & EX-C & 0.952 & 0.905 & 0.905 & 0.895 & 0.895 & 0.950 & Yes \\
\hline & MG-C & 0.937 & 0.877 & 0.877 & 0.860 & 0.860 & 0.935 & Yes \\
\hline & TC-C & 0.867 & 0.751 & 0.831 & 0.797 & 0.800 & 0.908 & Yes \\
\hline & TEC-C & 0.912 & 0.831 & 0.752 & 0.917 & 0.919 & 0.938 & Yes \\
\hline $\begin{array}{c}\text { Dependent } \\
\text { variable }\end{array}$ & TECH-P & 0.868 & 0.753 & 0.754 & 0.836 & 0.835 & 0.902 & Yes \\
\hline Mediating & TIC-C & 0.912 & 0.831 & 0.748 & 0.887 & 0.888 & 0.922 & Yes \\
\hline variable & TM-C & 0.876 & 0.767 & 0.767 & 0.899 & 0.902 & 0.929 & Yes \\
\hline
\end{tabular}

The abbreviation of latent variables* is as follows. Management Capability (MG-C), Technology Capability (TEC-C), Exit Capability (EXC), Technology Commercialization Capability (TC-C), Technology Innovation Competency (TIC-C), Technology Marketing Competency (TM-C), Technical Performance (TECH-P).

Convergent validity was assessed by outer loadings, measurement variable reliability, and AVE. The measurement variables' external loads were all over the threshold of 0.7 , indicating a concentration validity. The results of external loading and cross-loading analysis are shown in Tables 2 and 3. 
ENTREPRENEURSHIP AND SUSTAINABILITY ISSUES

ISSN 2345-0282 (online) http://jssidoi.org/jesi/

2020 Volume 8 Number 2 (December)

http://doi.org/10.9770/jesi.2020.8.2(67)

Make your research more visible, join the Twitter account of ENTREPRENEURSHIP AND SUSTAINABILITY ISSUES: @Entrepr69728810

Tables 2. Evaluation results of measurement model (outer loadings)

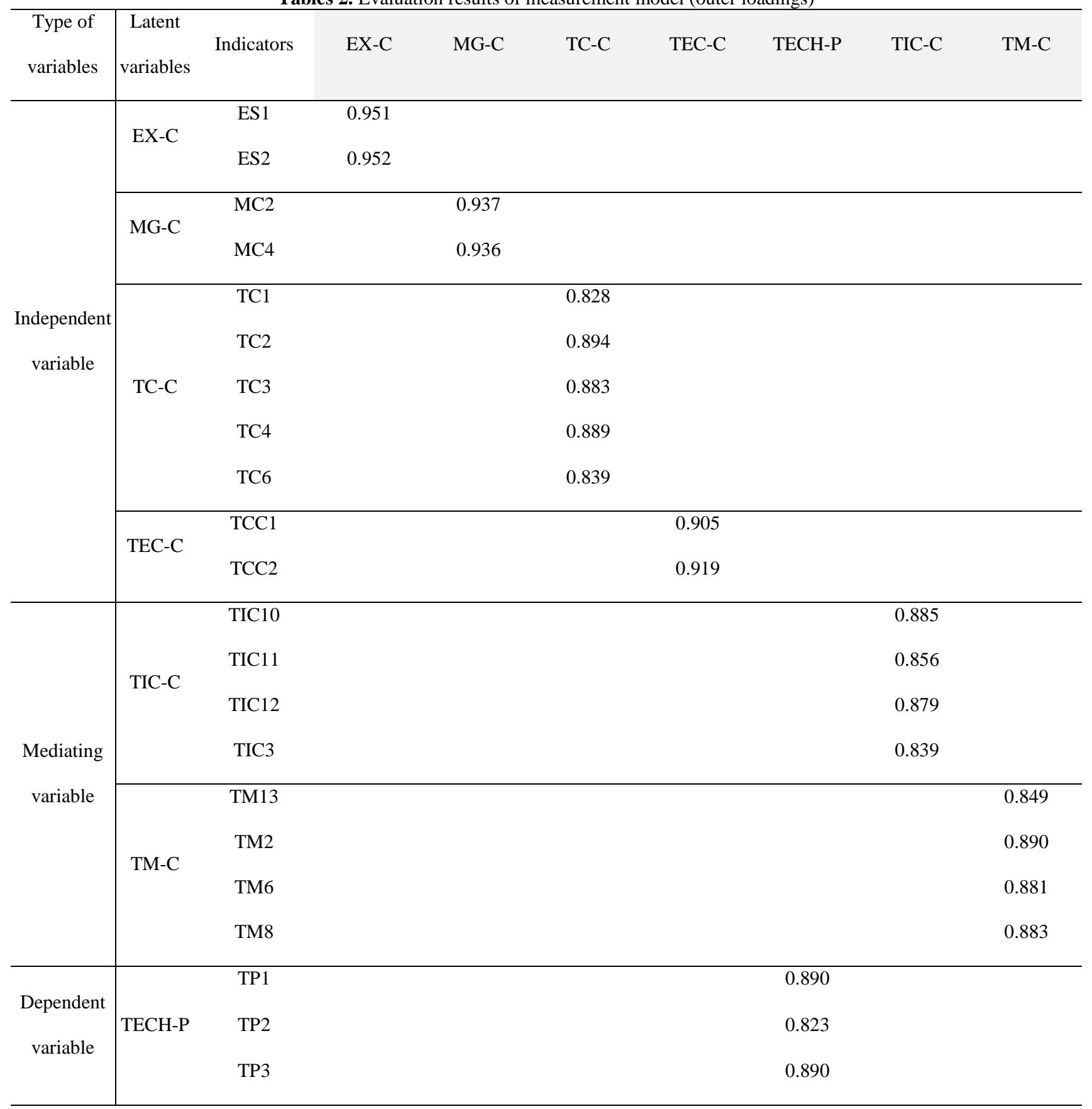

As shown in Table 1, the Average Variance Extracted (AVE) value, which is another criterion of the concentration validity, also confirmed that the convergent validity was secured as all the measured variables were 
Make your research more visible, join the Twitter account of ENTREPRENEURSHIP AND SUSTAINABILITY ISSUES: @Entrepr69728810

the threshold value of 0.5 or more. Fornell-Larcker Criterion (FLC), Cross Loadings are presented as criteria for determining the reflective measurement model's discriminant validity. FLC is a criterion for determining discriminant validity. Since the square root of the AVE of the diagonal is larger than the correlation between the study variables below the diagonal, the discriminant validity between study variables is evaluated. The results are shown in Table 4.

Tables 3. Evaluation results of measurement model (cross-loadings)

\begin{tabular}{|c|c|c|c|c|c|c|c|c|}
\hline Latent variables & Indicators & EX-C & MG-C & TC-C & TEC-C & TECH-P & TIC-C & TM-C \\
\hline \multirow{2}{*}{ EX-C } & ES1 & 0.949 & 0.747 & 0.682 & 0.608 & 0.580 & 0.671 & 0.533 \\
\hline & ES2 & 0.954 & 0.666 & 0.648 & 0.658 & 0.575 & 0.682 & 0.564 \\
\hline \multirow{2}{*}{ MG-C } & $\mathrm{MC} 2$ & 0.656 & 0.906 & 0.744 & 0.634 & 0.606 & 0.601 & 0.470 \\
\hline & MC4 & 0.744 & 0.902 & 0.781 & 0.646 & 0.553 & 0.648 & 0.588 \\
\hline \multirow{5}{*}{ TC-C } & $\mathrm{TC} 1$ & 0.469 & 0.752 & 0.480 & 0.645 & 0.614 & 0.477 & 0.383 \\
\hline & $\mathrm{TC} 2$ & 0.641 & 0.731 & 0.950 & 0.636 & 0.559 & 0.571 & 0.608 \\
\hline & TC3 & 0.688 & 0.782 & 0.952 & 0.660 & 0.596 & 0.598 & 0.629 \\
\hline & TC4 & 0.690 & 0.644 & 0.565 & 0.645 & 0.562 & 0.887 & 0.623 \\
\hline & TC6 & 0.602 & 0.513 & 0.498 & 0.588 & 0.554 & 0.892 & 0.580 \\
\hline \multirow{2}{*}{ TEC-C } & TCC1 & 0.631 & 0.588 & 0.513 & 0.629 & 0.576 & 0.909 & 0.625 \\
\hline & TCC2 & 0.600 & 0.657 & 0.601 & 0.651 & 0.520 & 0.864 & 0.625 \\
\hline \multirow{4}{*}{ TIC-C } & TIC10 & 0.633 & 0.640 & 0.613 & 0.841 & 0.652 & 0.646 & 0.627 \\
\hline & TIC11 & 0.417 & 0.562 & 0.488 & 0.852 & 0.662 & 0.553 & 0.495 \\
\hline & TIC12 & 0.550 & 0.633 & 0.560 & 0.826 & 0.666 & 0.592 & 0.572 \\
\hline & TIC3 & 0.483 & 0.545 & 0.495 & 0.781 & 0.615 & 0.458 & 0.467 \\
\hline \multirow{4}{*}{ TM-C } & TM13 & 0.638 & 0.685 & 0.654 & 0.803 & 0.710 & 0.645 & 0.523 \\
\hline & TM2 & 0.610 & 0.698 & 0.667 & 0.872 & 0.726 & 0.668 & 0.512 \\
\hline & TM6 & 0.581 & 0.603 & 0.526 & 0.834 & 0.754 & 0.561 & 0.491 \\
\hline & TM8 & 0.484 & 0.556 & 0.501 & 0.834 & 0.651 & 0.562 & 0.509 \\
\hline \multirow{3}{*}{ TECH-P } & TP1 & 0.533 & 0.598 & 0.479 & 0.700 & 0.880 & 0.605 & 0.478 \\
\hline & TP2 & 0.576 & 0.658 & 0.640 & 0.763 & 0.884 & 0.566 & 0.619 \\
\hline & TP3 & 0.402 & 0.436 & 0.374 & 0.592 & 0.761 & 0.379 & 0.308 \\
\hline
\end{tabular}


ENTREPRENEURSHIP AND SUSTAINABILITY ISSUES

ISSN 2345-0282 (online) http://jssidoi.org/jesi/

2020 Volume 8 Number 2 (December)

http://doi.org/10.9770/jesi.2020.8.2(67)

Make your research more visible, join the Twitter account of ENTREPRENEURSHIP AND SUSTAINABILITY ISSUES: @Entrepr69728810

Tables 4. Evaluation results of the measurement model

\begin{tabular}{|c|c|c|c|c|c|c|c|}
\hline Latent variables & EX-C & MG-C & TC-C & TEC-C & TECH-P & TIC-C & TM-C \\
\hline EX-C & 0.952 & & & & & & \\
\hline MG-C & 0.748 & 0.937 & & & & & \\
\hline TC-C & 0.609 & 0.632 & 0.912 & & & & \\
\hline TEC-C & 0.733 & 0.705 & 0.656 & 0.867 & & & \\
\hline TECH-P & 0.769 & 0.847 & 0.664 & 0.820 & 0.868 & & \\
\hline TIC-C & 0.704 & 0.716 & 0.676 & 0.785 & 0.793 & 0.865 & \\
\hline TM-C & 0.722 & 0.708 & 0.601 & 0.786 & 0.848 & 0.797 & 0.876 \\
\hline
\end{tabular}

\section{Evaluation of the structural model}

The structural model's evaluation can be seen as a procedure to confirm the research model designed and developed by the researcher and confirm that the structural model is suitable. Once the structural model is found to be a suitable model, hypothesis testing can be performed. This study evaluated and confirmed multicollinearity, coefficient of determination $\left(\mathrm{R}^{2}\right)$, effect size $\left(\mathrm{f}^{2}\right)$, and predictive suitability $\left(\mathrm{Q}^{2}\right)$ for evaluation of structural model in PLS-SEM. Table 5 shows the verifying of the internal VIF value by executing the PLS algorithm to confirm multicollinearity. If the Inner VIF Values among the study variables are less than 5, it can be judged that there is no multicollinearity. As a result, all of them are less than 5, so it can be estimated that there is no multicollinearity. Evaluate the explanatory power of the endogenous research variables, the results of verifying the coefficient of determination $\mathrm{R}^{2}$ by executing the PLS algorithm are shown in Table 6 . The effect size $\left(\mathrm{f}^{2}\right)$ is used as a criterion for evaluating the relative influence of exogenous study variables (or predictors or independent variables) on the endogenous study variables. If $\mathrm{f}^{2}$ is 0.02 , it is evaluated as a small effect size, 0.15 as a medium effect size, and 0.35 as a big effect size. Table 7 shows the results of checking the effect size $\left(\mathrm{f}^{2}\right)$. Evaluate whether the structural model has predictive suitability for specific endogenous study variables. For this purpose, predictive suitability $\left(\mathrm{Q}^{2}\right)$ is used. If the structural model is $\mathrm{Q}^{2}$ greater than 0 for a specific endogenous study variable, it is predicted to be predictive fit. Blindfolding of Smart PLS 3.2.9 was performed to confirm the results of Cross-Validated Redundancy and to evaluate $\mathrm{Q}^{2}$. The results are shown in Table 8.

Tables 5. Inner VIF

\begin{tabular}{c|cccc}
\hline Type of variables & Indicators & TECH-P & TIC-C & TM-C \\
\hline \multirow{3}{*}{ Independent variable } & EX-C & 2.992 & 2.852 & 2.852 \\
& MG-C & 2.915 & 2.731 & 2.731 \\
& TC-C & 2.106 & 1.979 & 1.979 \\
& TEC-C & 3.659 & 2.714 & 2.714 \\
\hline Mediating & TIC-C & 3.804 & & \\
variable & TM-C & 3.634 & & \\
\hline
\end{tabular}


ENTREPRENEURSHIP AND SUSTAINABILITY ISSUES

ISSN 2345-0282 (online) http://jssidoi.org/jesi/

2020 Volume 8 Number 2 (December)

http://doi.org/10.9770/jesi.2020.8.2(67)

Make your research more visible, join the Twitter account of ENTREPRENEURSHIP AND SUSTAINABILITY ISSUES: @Entrepr69728810

Tables 6. R square

\begin{tabular}{c|ccc}
\hline Type of variables & Indicators & R Square & Adjusted R Square \\
\hline Dependent variable & TECH-P & 0.863 & 0.858 \\
\hline Mediating & TIC-C & 0.696 & 0.690 \\
variable & TM-C & 0.682 & 0.675 \\
\hline
\end{tabular}

Tables 7. Effect size $\left(\mathrm{f}^{2}\right)$

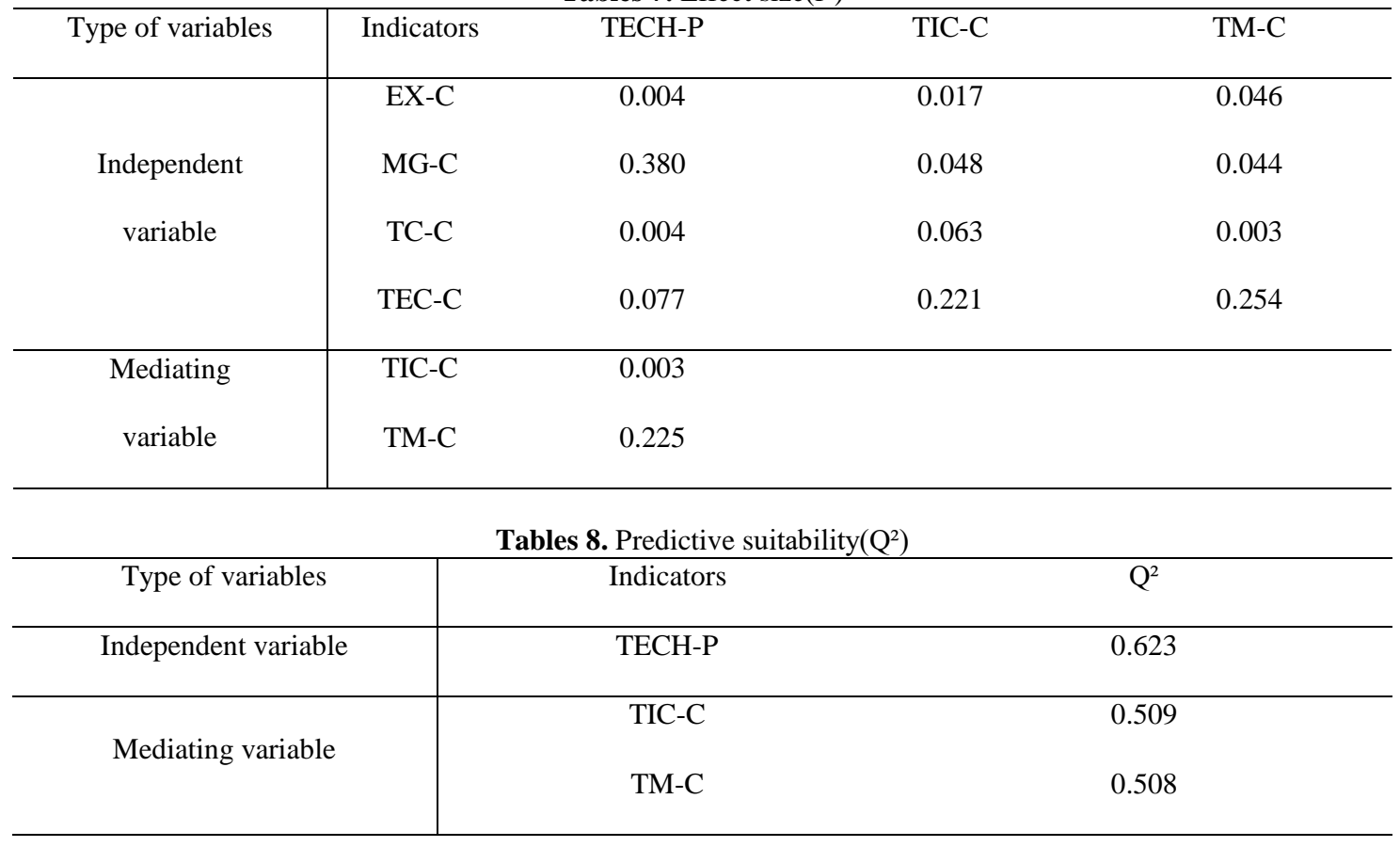

\section{Verification of hypotheses}

Since the structural model's evaluation is appropriate, the hypothesis verification can be carried out through bootstrapping. The significance and adequacy of the path coefficient are evaluated using the $t$ value calculated through the execution of bootstrapping. Through this, a hypothesis test was conducted. Bootstrapping of Smart PLS 3.2.9 carried out the significance and suitability evaluation of the path coefficients. It was verified by checking the t-value, p-value, and confidence interval required for hypothesis testing at the significance level of .05 . The results are shown in Tables 9 and Figure 3. 
ENTREPRENEURSHIP AND SUSTAINABILITY ISSUES

ISSN 2345-0282 (online) http://jssidoi.org/jesi/

2020 Volume 8 Number 2 (December)

http://doi.org/10.9770/jesi.2020.8.2(67)

Make your research more visible, join the Twitter account of ENTREPRENEURSHIP AND SUSTAINABILITY ISSUES: @Entrepr69728810

Tables 9. Hypothesis verification results

\begin{tabular}{|c|c|c|c|c|c|c|c|c|c|}
\hline \multirow{3}{*}{ Hypothesis } & \multirow{3}{*}{ Path } & \multirow{3}{*}{$\begin{array}{l}\text { Original } \\
\text { sample } \\
\text { (O) }\end{array}$} & \multirow{3}{*}{$\begin{array}{c}\text { Sample } \\
\text { mean } \\
\text { (M) }\end{array}$} & \multirow{3}{*}{$\begin{array}{l}\text { Standard } \\
\text { deviation } \\
\text { (STDEV) }\end{array}$} & \multirow{3}{*}{$\begin{array}{c}\text { T statistics } \\
(|\mathrm{O} / \mathrm{STDEV}|)\end{array}$} & \multirow{3}{*}{$\begin{array}{c}\mathrm{P}- \\
\text { value }\end{array}$} & \multicolumn{2}{|c|}{ Confidence } & \multirow[b]{2}{*}{ Significance } \\
\hline & & & & & & & & rval & \\
\hline & & & & & & & $2.5 \%$ & $97.5 \%$ & $(\mathrm{p}<0.05)$ \\
\hline \multirow{5}{*}{$\mathrm{H} 1$} & $E X-C \rightarrow T M-C$ & 0.204 & 0.208 & 0.098 & 2.086 & 0.037 & 0.003 & 0.396 & Yes \\
\hline & $M G-C \rightarrow T I C-C$ & 0.200 & 0.203 & 0.081 & 2.465 & 0.014 & 0.042 & 0.359 & Yes \\
\hline & $T C-C \rightarrow T I C-C$ & 0.195 & 0.191 & 0.075 & 2.588 & 0.010 & 0.043 & 0.333 & Yes \\
\hline & $T E C-C \rightarrow T I C-C$ & 0.427 & 0.433 & 0.089 & 4.817 & 0.000 & 0.251 & 0.591 & Yes \\
\hline & $T E C-C \rightarrow T M-C$ & 0.469 & 0.467 & 0.111 & 4.238 & 0.000 & 0.244 & 0.684 & Yes \\
\hline $\mathrm{H} 2$ & $T M-C \rightarrow T E C H-P$ & 0.335 & 0.333 & 0.086 & 3.890 & 0.000 & 0.161 & 0.501 & Yes \\
\hline \multirow{2}{*}{ H3 } & $M G-C \rightarrow T E C H-P$ & 0.390 & 0.379 & 0.062 & 6.281 & 0.000 & 0.277 & 0.517 & Yes \\
\hline & $T E C-C \rightarrow T E C H-P$ & 0.196 & 0.192 & 0.083 & 2.369 & 0.018 & 0.047 & 0.361 & Yes \\
\hline
\end{tabular}

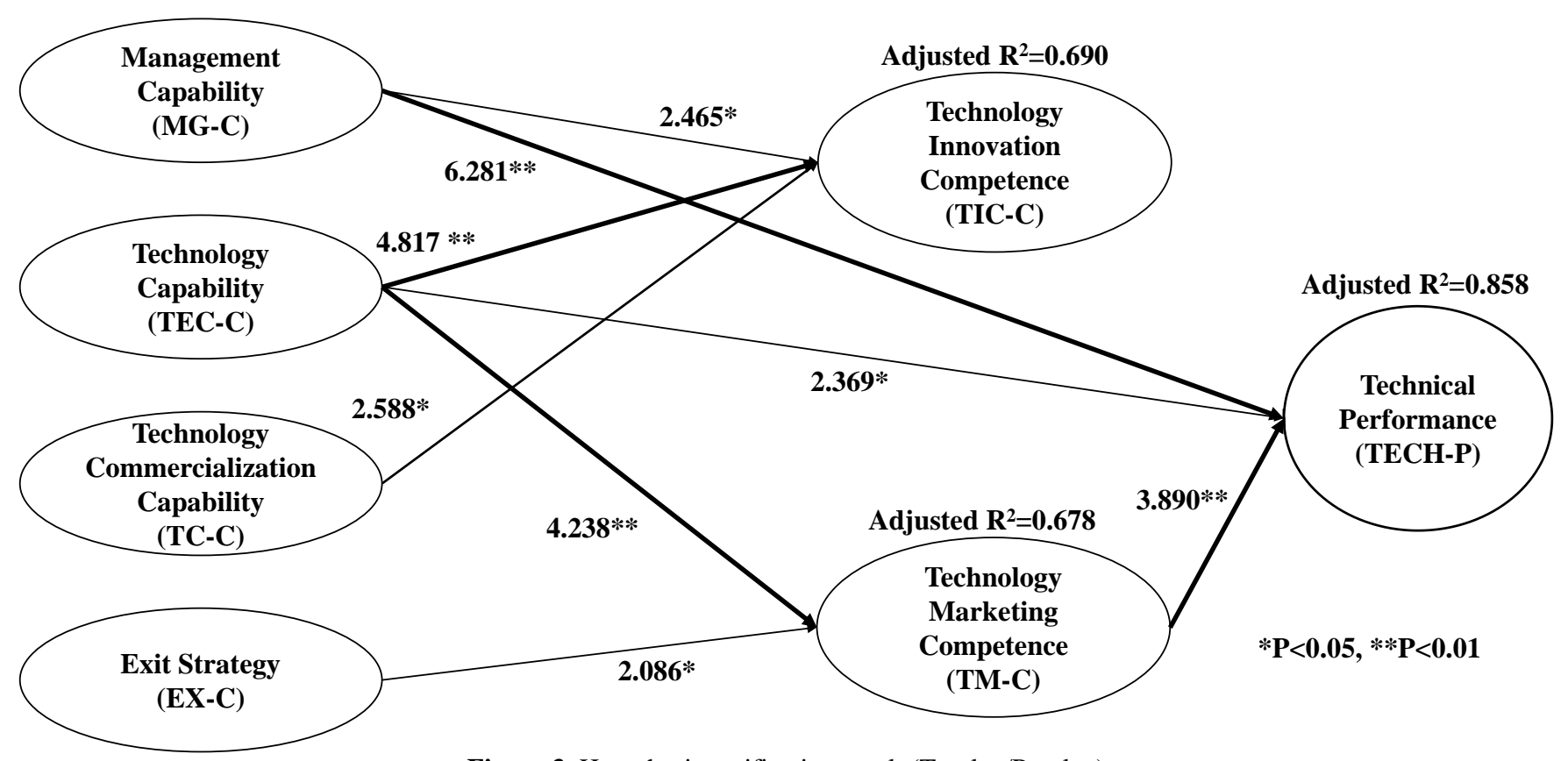

Figure 3. Hypothesis verification result (T-value/P-value)

As a result of hypothesis verification, as shown in Tables 9 and Figure 3, the critical and significant paths are as follows. Hypothesis 1: Technology capability (TEC-C) had a significant influence on both technical marketing (TM-C) and technological innovation capability (TIC-C). Hypothesis 2: Technical marketing competency (TM-C) 
Make your research more visible, join the Twitter account of ENTREPRENEURSHIP AND SUSTAINABILITY ISSUES: @Entrepr69728810

strongly influenced technical performance (TECH-P). Hypothesis 3: MG-C $\rightarrow$ TECH-P, Management Capability (MG-C) strongly influenced technical performance (TECH-P).

\section{Moderation effect verification}

According to the industrial classification, the moderation effect on the Technical Performance was significant with the path coefficient of .114, the T-statistic of 1.782, and the P-Value of .075 ( $\mathrm{p}<.10)$. The results are shown in Tables 10 and Figure 4.

Tables 10. Verification results of moderation effect

\begin{tabular}{|c|c|c|c|c|c|c|c|}
\hline \multirow[t]{2}{*}{ Hypothesis } & \multirow[t]{2}{*}{ Path } & $\begin{array}{l}\text { Original } \\
\text { Sample }\end{array}$ & $\begin{array}{c}\text { Sample } \\
\text { Mean }\end{array}$ & $\begin{array}{l}\text { Standard } \\
\text { Deviation }\end{array}$ & T statistics & \multirow{2}{*}{$\begin{array}{c}\text { P- } \\
\text { Value }\end{array}$} & Significance \\
\hline & & (O) & (M) & (STDEV) & $(|\mathrm{O} / \mathrm{STDEV}|)$ & & $(\mathrm{p}<0.10)$ \\
\hline \multirow{6}{*}{$H 1$} & $E X-C \rightarrow T M-C$ & 0.204 & 0.207 & 0.099 & 2.067 & 0.039 & Yes \\
\hline & $M G-C \rightarrow T I C-C$ & 0.200 & 0.203 & 0.082 & 2.442 & 0.015 & Yes \\
\hline & $M G-C \rightarrow T M-C$ & 0.195 & 0.193 & 0.114 & 1.712 & 0.087 & Yes \\
\hline & $T C-C \rightarrow T I C-C$ & 0.195 & 0.192 & 0.074 & 2.645 & 0.008 & Yes \\
\hline & $T E C-C \rightarrow T I C-C$ & 0.427 & 0.433 & 0.091 & 4.682 & 0.000 & Yes \\
\hline & $T E C-C \rightarrow T M-C$ & 0.469 & 0.470 & 0.110 & 4.253 & 0.000 & Yes \\
\hline$H 2$ & $T M-C \rightarrow T E C H-P$ & 0.337 & 0.326 & 0.087 & 3.863 & 0.000 & Yes \\
\hline \multirow{3}{*}{$H 3$} & $T E C-C \rightarrow T E C H-P$ & 0.399 & 0.393 & 0.085 & 4.689 & 0.000 & Yes \\
\hline & $E X-C \rightarrow T E C H-P$ & 0.123 & 0.139 & 0.067 & 1.841 & 0.066 & Yes \\
\hline & $M G-C \rightarrow T E C H-P$ & 0.437 & 0.429 & 0.071 & 6.153 & 0.000 & Yes \\
\hline Moderation & $T C-C \rightarrow D I V \rightarrow T E C H-P$ & 0.114 & 0.122 & 0.064 & 1.782 & 0.075 & Yes \\
\hline
\end{tabular}

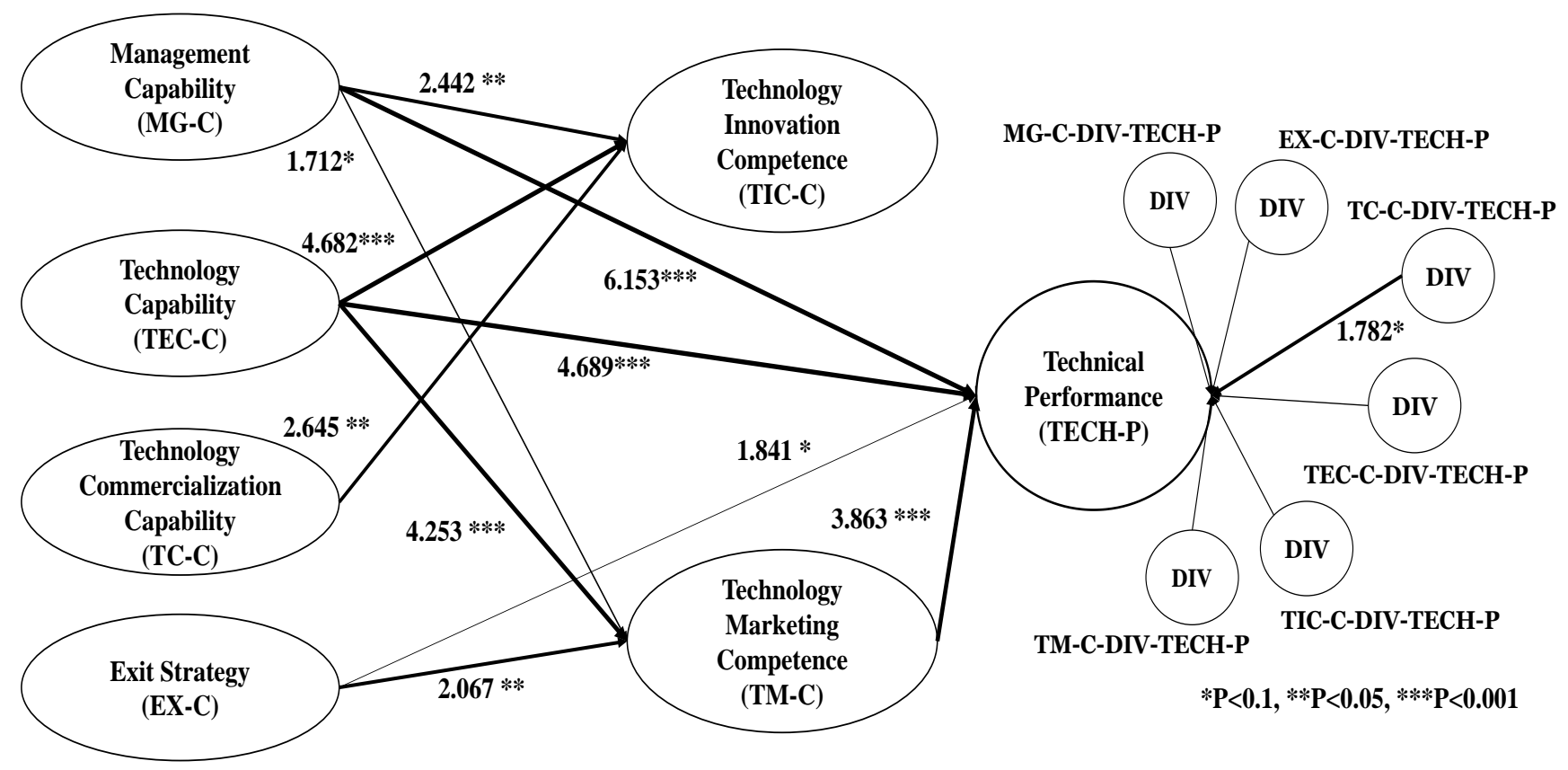


Make your research more visible, join the Twitter account of ENTREPRENEURSHIP AND SUSTAINABILITY ISSUES: @Entrepr69728810

Figure 4. Moderation effect verification result (T-value, P-value)

As shown in Table 10 and Figure 4, it was confirmed that the impact factors on technical performance differ by industry. In particular, technology commercialization capability affects technical performance due to the moderating effect of industrial classification. This result proved the study's purpose that the influence factors showing the modulating effect will differ depending on the industry sector. A data group analysis was conducted to verify what latent variables have different effects depending on the industry sector and whether there are differences between industries.

\section{Analysis result of technical performance impact by industry sectors}

We compared and verified the differences between $\mathrm{R}^{2}, \mathrm{f}^{2}$, total indirect effects, specific indirect effects, and total effects on the Technical Performance impacts of six industries. Six industries are DIV 1 (electrics/electronics), DIV 2 (machinery/parts), DIV 3 (IT/SW), DIV 4 (chemicals/ textiles/ materials), DIV 5 (life/food), DIV 6 (crafts/others). We used Data Group Analysis to identify differences in Technical Performance according to six industry classification. The results are shown in Tables 11 to 15.

Table 11. $\mathrm{R}^{2}$ Result of technical performance impact by industry sectors

\begin{tabular}{cccccccc}
\hline Adjusted Square & Overall* & DIV 1** & DIV 2** & DIV 3** & DIV 4** & DIV 5** & DIV 6** \\
\hline TECH-P & 0.858 & 0.810 & 0.896 & 0.868 & 0.905 & 0.960 & 0.897 \\
TIC-C & 0.690 & 0.719 & 0.681 & 0.796 & 0.616 & 0.901 & 0.753 \\
TM-C & 0.675 & 0.600 & 0.765 & 0.814 & 0.560 & 0.626 & 0.723 \\
\hline
\end{tabular}

Table 12. $\mathrm{f}^{2}$ Result of technical performance impact by industry sectors

\begin{tabular}{ccccccccccc}
\hline \multirow{2}{*}{$\mathrm{f}^{2}$} & \multicolumn{3}{c}{ DIV 1 } & \multicolumn{3}{c}{ DIV 2 } & \multicolumn{3}{c}{ DIV 3 } \\
\cline { 2 - 8 } & TECH-P & TIC-C & TM-C & TECH-P & TIC-C & TM-C & TECH-P & TIC-C & TM-C \\
\hline EX-C & 0.002 & 0.040 & 0.011 & 0.286 & 0.029 & 0.121 & 0.010 & 0.342 & 0.001 \\
MG-C & 0.190 & 0.162 & 0.332 & $\mathbf{1 . 3 3 4}$ & 0.069 & 0.001 & 0.000 & 0.050 & 0.032 \\
TC-C & 0.034 & 0.220 & 0.019 & 0.272 & 0.235 & 0.004 & 0.190 & 0.061 & 0.001 \\
TEC-C & 0.097 & 0.270 & 0.291 & 0.005 & 0.184 & 0.390 & 0.249 & 0.625 & 1.065 \\
TIC-C & 0.025 & & & 0.014 & & & 0.025 & 0.009 \\
TM-C & 0.333 & & & 0.056 & & & & 0 \\
\hline
\end{tabular}

Table 13. $\mathrm{f}^{2}$ Result of technical performance impact by industry sectors(continued)

\begin{tabular}{ccccccccccc}
\hline \multirow{2}{*}{$\mathrm{f}^{2}$} & \multicolumn{3}{c}{ DIV 4 } & \multicolumn{3}{c}{ DIV 5 } & \multicolumn{3}{c}{ DIV 6 } \\
\cline { 2 - 9 } & TECH-P & TIC-C & TM-C & TECH-P & TIC-C & TM-C & TECH-P & TIC-C & TM-C \\
\hline EX-C & 0.023 & 0.017 & 0.093 & 0.116 & 0.073 & 0.142 & 0.085 & 0.141 & 0.435 \\
MG-C & 0.401 & 0.040 & 0.136 & $\mathbf{1 . 3 0 4}$ & 0.260 & 0.001 & 0.281 & 0.001 & 0.050 \\
TC-C & 0.003 & 0.047 & 0.002 & 0.098 & 0.119 & 0.003 & 0.114 & 0.086 & 0.024 \\
TEC-C & 0.001 & 0.159 & 0.201 & $\mathbf{0 . 5 7 7}$ & 0.289 & 0.038 & 0.103 & 0.485 & 0.087 \\
TIC-C & 0.129 & & & 0.041 & & & 0.001 & \\
TM-C & 0.237 & & & $\mathbf{2 . 4 1 2}$ & & & $\mathbf{0 . 9 8 6}$ \\
\hline
\end{tabular}


ISSN 2345-0282 (online) http://jssidoi.org/jesi/ 2020 Volume 8 Number 2 (December)

http://doi.org/10.9770/jesi.2020.8.2(67)

Make your research more visible, join the Twitter account of ENTREPRENEURSHIP AND SUSTAINABILITY ISSUES: @Entrepr69728810

Table 14. Total indirect effect of technical performance impact by industry sectors

\begin{tabular}{|c|c|c|c|c|c|c|c|}
\hline \multirow{2}{*}{ Total Indirect Effect } & Overall & DIV 1 & DIV 2 & \multirow{2}{*}{$\begin{array}{c}\text { DIV } 3 \\
\text { TECH-P }\end{array}$} & \multirow[t]{2}{*}{ DIV 4} & \multirow[t]{2}{*}{ DIV 5} & \multirow[t]{2}{*}{ DIV 6} \\
\hline & & & & & & & \\
\hline EX-C & 0.074 & 0.074 & -0.021 & 0.053 & -0.061 & -0.076 & 0.261 \\
\hline MG-C & 0.074 & 0.074 & 0.253 & 0.017 & 0.045 & 0.205 & -0.058 \\
\hline TC-C & 0.023 & 0.023 & 0.081 & 0.048 & 0.029 & -0.059 & 0.005 \\
\hline TEC-C & 0.174 & 0.174 & 0.234 & 0.184 & 0.027 & 0.252 & 0.085 \\
\hline & Table 15. Sp & ecial indirect & ffect of techn & al performai & impact & & \\
\hline Special Indirect Effect & Overall & DIV 1 & DIV 2 & DIV 3 & DIV 4 & DIV 5 & DIV 6 \\
\hline $\mathrm{EX}-\mathrm{C} \rightarrow \mathrm{TIC}-\mathrm{C} \rightarrow \mathrm{TECH}-\mathrm{P}$ & 0.005 & 0.022 & -0.017 & -0.062 & 0.036 & -0.027 & 0.006 \\
\hline $\mathrm{MG}-\mathrm{C} \rightarrow \mathrm{TIC}-\mathrm{C} \rightarrow \mathrm{TECH}-\mathrm{P}$ & 0.008 & 0.041 & 0.023 & 0.031 & 0.058 & -0.037 & -0.001 \\
\hline $\mathrm{TC}-\mathrm{C} \rightarrow \mathrm{TIC}-\mathrm{C} \rightarrow \mathrm{TECH}-\mathrm{P}$ & 0.008 & 0.039 & 0.038 & 0.027 & -0.047 & -0.023 & 0.005 \\
\hline $\mathrm{TEC}-\mathrm{C} \rightarrow \mathrm{TIC}-\mathrm{C} \rightarrow \mathrm{TECH}-\mathrm{P}$ & 0.017 & 0.049 & 0.048 & 0.127 & 0.100 & -0.048 & 0.013 \\
\hline $\mathrm{EX}-\mathrm{C} \rightarrow \mathrm{TM}-\mathrm{C} \rightarrow \mathrm{TECH}-\mathrm{P}$ & 0.069 & -0.043 & 0.070 & 0.002 & -0.112 & 0.288 & 0.283 \\
\hline MG-C $\rightarrow$ TM-C $\rightarrow$ TECH-P & 0.066 & 0.213 & -0.006 & 0.015 & 0.146 & -0.021 & 0.099 \\
\hline $\mathrm{TC}-\mathrm{C} \rightarrow \mathrm{TM}-\mathrm{C} \rightarrow \mathrm{TECH}-\mathrm{P}$ & 0.015 & 0.042 & 0.010 & 0.002 & -0.012 & 0.027 & 0.072 \\
\hline TEC-C $\rightarrow$ TM-C $\rightarrow$ TECH-P & 0.157 & 0.185 & 0.137 & -0.100 & 0.152 & 0.133 & 0.145 \\
\hline
\end{tabular}

Table 16. Total effect of technical performance impact by industry sectors

\begin{tabular}{|c|c|c|c|c|c|c|c|c|c|c|c|c|}
\hline \multirow{2}{*}{$\begin{array}{l}\text { Total } \\
\text { Effect }\end{array}$} & \multicolumn{3}{|c|}{ Overall } & \multicolumn{3}{|c|}{ DIV 1} & \multicolumn{3}{|c|}{ DIV 2} & \multicolumn{3}{|c|}{ DIV 3} \\
\hline & TECH-P & TIC-C & TM-C & TECH-P & TIC-C & TM-C & TECH-P & TIC-C & TM-C & TECH-P & TIC-C & TM-C \\
\hline $\mathrm{EX}-\mathrm{C}$ & 0.114 & 0.122 & 0.204 & 0.010 & 0.157 & -0.100 & 0.427 & -0.174 & 0.309 & 0.009 & -0.427 & -0.016 \\
\hline MG-C & 0.464 & 0.200 & 0.195 & 0.547 & 0.291 & 0.497 & 0.624 & 0.230 & -0.025 & 0.044 & 0.210 & -0.159 \\
\hline TC-C & 0.058 & 0.195 & 0.046 & -0.016 & 0.278 & 0.098 & -0.222 & 0.383 & 0.045 & 0.292 & 0.184 & -0.020 \\
\hline TEC-C & 0.371 & 0.427 & 0.469 & 0.432 & 0.350 & 0.433 & 0.133 & 0.483 & 0.602 & 0.650 & 0.868 & 1.080 \\
\hline TIC-C & 0.041 & & & 0.140 & & & 0.099 & & & 0.146 & & \\
\hline TM-C & 0.335 & & & 0.427 & & & 0.227 & & & -0.092 & & \\
\hline
\end{tabular}


ENTREPRENEURSHIP AND SUSTAINABILITY ISSUES

ISSN 2345-0282 (online) http://jssidoi.org/jesi/

2020 Volume 8 Number 2 (December)

http://doi.org/10.9770/jesi.2020.8.2(67)

Make your research more visible, join the Twitter account of ENTREPRENEURSHIP AND SUSTAINABILITY ISSUES: @Entrepr69728810

Table 17. Total effect of technical performance impact by industry sectors(continued)

\begin{tabular}{|c|c|c|c|c|c|c|c|c|c|}
\hline \multirow{2}{*}{ Total Effect } & \multicolumn{3}{|c|}{ DIV 4} & \multicolumn{3}{|c|}{ DIV 5} & \multicolumn{3}{|c|}{ DIV 6} \\
\hline & TECH-P & TIC-C & TM-C & TECH-P & TIC-C & TM-C & TECH-P & TIC-C & TM-C \\
\hline EX-C & 0.040 & 0.196 & -0.485 & 0.084 & 0.213 & 0.579 & 0.133 & 0.258 & 0.480 \\
\hline MG-C & 0.726 & 0.321 & 0.634 & 0.390 & 0.291 & -0.042 & 0.339 & -0.024 & 0.168 \\
\hline TC-C & -0.025 & -0.258 & -0.051 & 0.109 & 0.179 & 0.055 & 0.241 & 0.217 & 0.122 \\
\hline TEC-C & 0.223 & 0.547 & 0.660 & 0.451 & 0.376 & 0.267 & 0.354 & 0.548 & 0.246 \\
\hline TIC-C & 0.182 & & & -0.127 & & & 0.024 & & \\
\hline TM-C & 0.231 & & & 0.496 & & & 0.589 & & \\
\hline
\end{tabular}

In Table 11, $\mathrm{R}^{2}$ shows that DIV 1 (electrics/electronics) has a low impact on Technical Performance from .858 to .810 , but increases in all other DIV $2 \sim$ DIV 6. In Tables 12 and 13, $\mathrm{f}^{2}$ shows that factors affecting Technical Performance differ according to DIV, which means that learning and education methods that improve existing uniform abilities and competencies to create technological outcomes according to industries are different. Differently, it is essential to know that specialized education and learning for each industry sector is required. In Table 14, the total indirect effects were found to increase technological capability on Technical Performance except DIV 4 (chemicals/textiles/materials) and DIV 6 (crafts/others).

In Table 15, the Special Indirect Effect on Technical Performance is significant except for DIV 3 (IT/SW) and DIV 6 (crafts/others) when the technical capability is through the technology marketing capability. Electronics confirmed an increase in indirect effects. Besides, the exit strategy (EX-C) increased significantly in DIV 5 (life/food) and DIV 6 (crafts/others) via technology marketing. Overall, the technology marketing competency (TM-C) confirmed that the Special Indirect Effect was high. In Tables 16 and 17, the total effect on the Technical Performance was found to be increased in three or more factors: DIV 3 (IT/SW), DIV 1 (electrics/electronics), and DIV 5 (life/food). In particular, DIV 3 (IT/SW) found that the total effect of technology capability, technology innovation capability, and technology commercialization capability on technology performance was remarkably increased. It proves to be an essential factor for IT/SW companies to increase their Technical Performance.

\section{Conclusions and implications}

Given that young SMEs' success in the world is one of the essential policies for each country's future survival, this study examined the causal relationship between the degree and influence of factors affecting entrepreneurial capability and the influential drivers and technical performance.

We analyzed and verified whether the mediation effect is significant, and the impact on the business performance of six industries such as electrics/electronics, machinery/parts, IT/SW, chemicals/textiles/materials, life/food, crafts/others. 


\section{ENTREPRENEURSHIP AND SUSTAINABILITY ISSUES}

ISSN 2345-0282 (online) http://jssidoi.org/jesi/

2020 Volume 8 Number 2 (December)

http://doi.org/10.9770/jesi.2020.8.2(67)

Make your research more visible, join the Twitter account of ENTREPRENEURSHIP AND SUSTAINABILITY ISSUES: @Entrepr69728810

The moderating effects of how the factors differ and the degree of influence were verified. In particular, due to verifying the moderating effect on the industry sector's technical performance, it was confirmed that the technology capability is the main influence factor path on technical performance. As for the total effect on the Technical Performance, it was confirmed that DIV 3 (IT/SW), DIV 1 (electrics/electronics), and DIV 5 (life/food) increased the total effect on three or more factors. Mainly, DIV 3 (IT/SW) found that the total effect of technology capability, technology innovation capability, and technology commercialization capability on technology performance was remarkably increased. It proves to be an essential factor for IT/SW companies to increase their technical performance. In the information technology industry and the SoftWare industry, we are trying to survive and grow in the rapidly developing IT environment by making efforts to enhance technology capability, innovation capability, and technology commercialization capability by using Digital Transformation to create the technological performance.

This study suggests overcoming the failure of SMEs' technical performance and which capability and competence in focusing on sustainability. Management capability and technical marketing competency were an important, influential driver for technical performance. Technology capability had a significant influence on both technical marketing and technological innovation capability. This study's results will be provided to government policymakers and practitioners of government support agencies to stimulate youth entrepreneurs' success.

The limitations of this study and future research subjects can be summarized as follows.

First, this study was conducted for the founding companies. However, the significant technology start-up companies' technical field was found in electronics/electronics, machinery/parts, IT/SW, chemicals/textiles/materials/, life/food, and crafts/others. In setting up the surveys into two fields, there was a failure to subdivide all possible technology fields to which technology start-up companies belong. In the future, it will be necessary to conduct further research on the technical fields that have been subdivided with the specification of the technical fields. Second, there was a practical limitation that the former founders could not be targeted in the part of the research that was limited to the youth founding academy in Korea. We will carry out future research as a research topic to include a broader range of founders, including technology startups by country, region, industrial complex, and industry. Third, some of the contents of the questionnaire conducted in this study were focused on the manufacturing field, so there were practical limitations that it was difficult to reflect as many diverse and technical founders as possible.

Groups of technologies in the future can be categorized into manufacturing, non-manufacturing, IT, and industry 4.0, or the eight projects included in the innovation growth performances and future plans jointly announced by related ministries as reporting items for the Korea Innovation Growth Conference. It is necessary to expand further to the core leading business and conduct further research, and to conduct future research as an in-depth research topic following this research.

\section{References}

Andreou, P. C., Karasamani, I., Louca, C., and Ehrlich, D. 2017. The impact of managerial ability on crisis-period corporate investment. Journal of Business Research 79: 107-122. https://doi.org/10.1016/j.jbusres.2017.05.022

Autio, E. 1997. New, technology-based firms in innovation networks symplectic and generative impacts. Research policy $26(3): 263-281$. https://doi.org/10.1016/S0048-7333(96)00906-7

Bae, H., Song, M., and Kim, S. 2018. A Study on the Impact of Competency of Technology: Based Startups on Performance Using ETRI Technology. Asia-Pacific Journal of Business Venturing and Entrepreneurship 13(1): 61-72. 


\section{ENTREPRENEURSHIP AND SUSTAINABILITY ISSUES}

ISSN 2345-0282 (online) http://jssidoi.org/jesi/

2020 Volume 8 Number 2 (December)

http://doi.org/10.9770/jesi.2020.8.2(67)

Make your research more visible, join the Twitter account of ENTREPRENEURSHIP AND SUSTAINABILITY ISSUES: @Entrepr69728810

Bailetti, T. 2012. Technology entrepreneurship: overview, definition, and distinctive aspects. Technology Innovation Management Review 2(2): 5-12. http://doi.org/10.22215/timreview/520

Bollinger, L., Hope, K., and Utterback, J. M. 1983. A review of literature and hypotheses on new technology-based firms. Research policy 12(1): 1-14. https://doi.org/10.1016/0048-7333(83)90023-9

Booz, and Allen and Hamilton. 1982. New products management for the 1980s. Booz, Allen and Hamilton.

Burgelman, R. A., and Sayles, L. R. 2004. Transforming invention into innovation: the conceptualization stage. Strategic Management of Technology and Innovation. McGraw-Hill, Boston, 682-690.

Burgelman, R. A., Christensen, C. M., and Wheelwright, S. C. 2008. Strategic management of technology and innovation. McGrawHill/Irwin.

Carland, J. W., Hoy, F., Boulton, W. R., and Carland, J. C. 1984. Differentiating small business owners from entrepreneurs. Academy of Management Review 9(2): 354-359. https://doi.org/10.5465/ AMR. 1984. 4277721

Chandler, G. N., and Hanks, S. H. 1994. Market attractiveness, resource-based capabilities, venture strategies, and venture performance. Journal of Business Venturing 9(4): 331-349. https://doi.org/10.1016/0883-9026(94)90011-6

Chandler, G. N., and Jansen, E. 1992. The founder's self-assessed competence and venture performance. Journal of Business Venturing 7(3): 223-236. https://doi.org/10.1016/0883-9026(92)90028-P

Clugston, C. O. 1995. High-Tech demands own new-product plan. Electronic news 41(2094): 33-36.

Coombs, J. E., and Bierly III, P. E. 2006. Measuring technological capability and performance. R\& D Management 36(4): 421-438. https://doi.org/10.1111/j.1467-9310.2006.00444.x

Cooper, A. C., Willard, G. E., and Woo, C. Y. 1986. Strategies of high performing new and small firms: A reexamination of the niche concept. Journal of Business Venturing 1(3): 247-260. https://doi.org/10.1016/0883-9026(86)90003-0

De Cleyn, S. H., and Braet, J. 2009. Research valorisation through spin-off ventures: Integration of existing concepts and typologies. World Review of Entrepreneurship, Management and Sustainable Development 5(4): 325-352. https://doi.org/10.1504/WREMSD.2009.031624

De Franco, G., Hope, O. K., and Lu, H. 2017. Managerial ability and bank-loan pricing. Journal of Business Finance and Accounting 44(910): 1315-1337. https://doi.org/10.1111/jbfa.12267

Dijkstra, T. K. 2010. Latent variables and indices: Herman Wold's basic design and partial least squares. In Handbook of Partial Least Squares (pp. 23-46). Springer, Berlin, Heidelberg.

Englis, P. D., Wakkee, I., and Van Der Sijde, P. 2007. Knowledge and networks in the global startup process. International Journal of Knowledge Management Studies 1(3/4): 497-514. https://doi.org/10.1504/IJKMS.2007.012538

Fischer, E., and Reuber, A. R. 2003. Support for rapid-growth firms: a comparison of the views of founders, government policymakers, and private sector resource providers. Journal of Small Business Management 41(4): 346-365. https://doi.org/10.1111/1540-627X.00087

García-Muiña, F. E., and Navas-López, J. E. 2007. Explaining and measuring success in new business: The effect of technological capabilities on firm results. Technovation 27(1-2): 30-46. https://doi.org/10.1016/j.technovation.2006.04.004

Guan, J., and Ma, N. 2003. Innovative capability and export performance of Chinese firms. Technovation 23(9): 737-747. https://doi.org/10.1016/S0166-4972(02)00013-5

Hair, J. F., Hult, G. T. M., Ringle, C. M., Sarstedt, M., and Thiele, K. O. 2017. Mirror, mirror on the wall: a comparative evaluation of composite-based structural equation modeling methods. Journal of the Academy of Marketing Science 45(5): 616-632. 


\section{ENTREPRENEURSHIP AND SUSTAINABILITY ISSUES}

ISSN 2345-0282 (online) http://jssidoi.org/jesi/

2020 Volume 8 Number 2 (December)

http://doi.org/10.9770/jesi.2020.8.2(67)

Make your research more visible, join the Twitter account of ENTREPRENEURSHIP AND SUSTAINABILITY ISSUES: @Entrepr69728810

Heirman, A., and Clarysse, B. 2004. How and why do research-based start-ups differ at founding? A resource-based configurational perspective. The Journal of Technology Transfer 29(3-4): 247-268. https://doi.org/10.1023/B:JOTT.0000034122.88495.0d

Hwang, W. S., Choi, H., and Shin, J. 2020. A mediating role of innovation capability between entrepreneurial competencies and competitive advantage. Technology Analysis and Strategic Management 32(1): 1-14. https://doi.org/10.1080/09537325.2019.1632430

Itami, H., and Numagami, T. 1992. Dynamic interaction between strategy and technology. Strategic Management Journal 13(S2): 119-135. https://doi.org/10.1002/smj.4250130204

Johannisson, B. 1986. Network strategies: management technology for entrepreneurship and change. International Small Business Journal, 5(1): 19-30. https://doi.org/10.1177/026624268600500102

Kim, J. Y., and Bang, H. Y. 2017. The Effects of Environmental Uncertainty on the Impact Strategy and Performance of Korean, US, and Japanese Firms: Focusing on Environmental Uncertainty in the Competition Sector. Korean Journal of Trade and Commerce 17(4): 135156.

Kim, J., Cho, J., and Lee, S. 2020. The Influence of Entrepreneurial Competences on Corporate Performance of Technology-based Startups. Journal of the Industrial Management System 43(1): 132-142. http://db.koreascholar.com/article.aspx?code=388698

Kim, K. C., and Suh, B. D. 2017. The Effects of Social Enterprise Characteristics and CEO's Management Capability on Business Performance: Focusing on Mediating Effects of Corporate Reputation. The Journal of Eurasian Studies 14(2): 47-80.

Kim, S.Y. 2014. A Study on the Corporate Exit Strategy of the owners of small and medium-sized enterprises - focused on the business succession of small and medium-sized enterprises. Master's Thesis, Sangmyung University.

Kim, Y. K., and Park, S. T. 2018. Effects of Absorptive Capacity on Technology Innovation and Commercialization Capacities and Management Performance. Journal of the Korea Convergence Society 9(12): 217-225. https://doi.org/10.15207/jkcs.2018.9.12.217

Kwon, O.H. 2009. Venture company's EXIT strategy and case study by type. Master's Thesis, Konkuk University.

Kortum, S., and Lerner, J. 2001 Does venture capital spur innovation? i Libecap, GD (red.) Entrepreneurial inputs and outcomes; New studies of entrepreneurship in the United States. Bingley: Emerald Group Publishing Limited.

Lall, S. 1992. Technological capabilities and industrialization. World Development 20(2): 165-186. https://doi.org/10.1016/0305750X(92)90097-F

Larsson, E., Hedelin, L., and Gärling, T. 2003. Influence of expert advice on expansion goals of small businesses in rural Sweden. Journal of Small Business Management 41(2): 205-212. https://doi.org/10.1111/1540-627X.00076

Lee, I. K., and Yang, D. W. 2016. An Empirical Study on the Effect of CEO Technological Capability on Management Performances: Focusing on mediating effect technological capability in SMEs. Asia-Pacific Journal of Business Venturing and Entrepreneurship 11(2): 167-182.

Miller, P., and Power, M. 2005. Calculating corporate failure. In Professional Competition and Professional Power (pp. 65-90). Routledge.

Nevens, T. M. 1990. Commercializing technology: what the best companies do. Planning review.

Pauceanu, A. M., Alpenidze, O., Edu, T., and Zaharia, R. M. 2019. What determinants influence students to start their own business? Empirical evidence from United Arab Emirates Universities. Sustainability 11(1): 92. https://doi.org/10.1080/14735903.2012.674400

Park, H.G., and Yang, D.W. 2018. An Empirical Study on the Effect of the Technological Commercialization Ability of the Initial Entrepreneurship on Management Performance: Focusing on the Moderating Effect of Technology Entrepreneurs in Manufacturing Industries. Journal of the Korean Entrepreneurship Society 1(1): 14.

Planko, J., Cramer, J., Hekkert, M. P., and Chappin, M. M. 2017. Combining the technological innovation systems framework with the entrepreneurs' perspective on innovation. Technology Analysis and Strategic Management 29(6): 614-625. https://doi.org/10.1080/09537325.2016.1220515 


\section{ENTREPRENEURSHIP AND SUSTAINABILITY ISSUES}

ISSN 2345-0282 (online) http://jssidoi.org/jesi/

2020 Volume 8 Number 2 (December)

http://doi.org/10.9770/jesi.2020.8.2(67)

Make your research more visible, join the Twitter account of ENTREPRENEURSHIP AND SUSTAINABILITY ISSUES: @Entrepr69728810

Prohorovs, A., Bistrova, J., and Ten, D. 2019. Startup Success Factors in the Capital Attraction Stage: Founders' Perspective. Journal of East-West Business 25(1): 26-51.

Ritter, J. R. 1984. The hot issue market of 1980. Journal of Business 57, no. 2 (April): 215-240.

Saunila, M. 2017. Innovation capability in achieving higher performance: perspectives of management and employees. Technology Analysis and Strategic Management 29(8): 903-916. https://doi.org/10.1080/09537325.2016.1259469

Schoenecker, T., and Swanson, L. 2002. Indicators of firm technological capability: validity and performance implications. IEEE Transactions on Engineering Management 49(1): 36-44. https://doi.org/10.1109/17.985746

Seo, Y. W., and Lee, Y. H. 2019. Effects of internal and external factors on business performance of start-ups in South Korea: The engine of new market dynamics. International Journal of Engineering Business Management 11. https://doi.org/10.1177/1847979018824231

Start-up Promotion Agency, 2019, 66-71, Korea National Statistical Approval No. 142016.

Stoel, M. D., and Muhanna, W. A. 2009. IT capabilities and firm performance: A contingency analysis of the role of industry and IT capability type. Information and Management 46(3): 181-189. https://doi.org/10.1016/j.im.2008.10.002

Wold, H. 1982. Soft modeling: the basic design and some extensions. Systems Under Indirect Observation 2: 343.

Yam, R. C., Guan, J. C., Pun, K. F., and Tang, E. P. 2004. An audit of technological innovation capabilities in Chinese firms: some empirical findings in Beijing, China. Research Policy 33(8): 1123-1140. https://doi.org/10.1016/j.respol.2004.05.004

Yoon, J. H. 2018. A Study on the Influence of Business Performance on Customer Orientation and Technology Capability of SMEs and Venture Business in Electric Power. Ph.D. dis., Konkuk University.

Zou, S., Fang, E., and Zhao, S. 2003. The effect of export marketing capabilities on export performance: an investigation of Chinese exporters. Journal of International Marketing 11(4): 32-55. https://doi.org/10.1509/jimk.11.4.32.20145

\section{Acknowledgment}

Hansung University, Korea, financially supported this research.

SEOK-SOO, KIM is the Director of the Global Entrepreneurs Foundation, Korea. Graduated from Seoul National University, KOREA. Doctoral at Hansung University, Dept. of Knowledge Sevice Consulting, Major in Management Consulting. Career: Professor of Youth-Start-up Entrepreneurs Academy (KOREA), Samsung Fine Chemicals (Rand D, KOREA), Kolon Industries (Technology Commercialization, KOREA), Master Black Belt (6 Sigma; DFSS at SAMSUNG, KOREA). Major research areas: SMEs' Performance, Startups \& Entrepreneurs, Technology Commercialization, Digital Transformation of SMEs, Global Entrepreneurship.

ORCID ID: orcid.org/0000-0003-3765-6890

Copyright (C) 2020 by author(s) and VsI Entrepreneurship and Sustainability Center This work is licensed under the Creative Commons Attribution International License (CC BY). http://creativecommons.org/licenses/by/4.0/

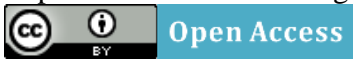

